\title{
Relationship Between Serum Ferritin Level and Hba1c in Bangladeshi Type 2 Diabetic Patients
}

\author{
*F Khondker1, MN Roy ${ }^{2}, \mathrm{PR} \mathrm{Saha}^{3}, \mathrm{R} \mathrm{Huq}^{4}$, R Ahmed ${ }^{5}, \mathrm{~S}$ Biswas $^{6}$
}

\begin{abstract}
Background: Diabetes mellitus (DM) type 2 is one of the most common endocrine disorders affecting more than 135 million people in the world. The etiology of the disease is not fully understood, but recently subclinical hemochromatosis has been considered as one of the probable causes of DM. This study was carried out to examine the relationship between serum ferritin as a marker of iron overload with DM and HbA1c.

Materials \& Method: This study was conducted in the Biochemistry department of Sir Salimullah Medical College, Dhaka; over a period of 18 months from July 2013 to December 2014. In this case control study, 46 patients with type 2 diabetes were taken as case, who were referred to theoutpatient department of "Ibrahim General Hospital \& Diabetic care \& Educational Center"(DCEC). 46 normal individuals were included as the control group, who were matched with the case group regarding age, sex, BMI and $\mathrm{Hb} \%$. Ferritin, hemoglobin, $\mathrm{HbA}_{1 \mathrm{c}}$ and fasting plasma sugar were measured in blood samples. Exclusion criteria included anaemia, or any other disease or drug that could affect ferritin levels.
\end{abstract}

Result: Results were analyzed statistically by Chi-square test, Student's t-test, Pearson correlation coefficient test and Odds ratio.Mean serum ferritin was significantly higher in diabetics than in the control group $(197.97 \pm 75.99 \mu \mathrm{gm} / \mathrm{L}$ vs. $64.24 \pm 27.83 \mu \mathrm{gm} / \mathrm{L}, \mathrm{p}<0.001)$. There was significant positive correlation between serum ferritin and HbA1cin diabetic patients $(\mathrm{p}<0.001)$. In this study, OR of 11.64 was also found.

Conclusion: Serum ferritin is positively correlated with type 2 Diabetes Mellitus. And this may be an important and independent predictor for development of diabetes mellitus.

Key Words: Diabetes mellitus, ferritin, HbA1c, relationship

\section{Introduction}

Diabetes mellitus (DM) is a group of common metabolic disorders that share the phenotype of hyperglycemia. It is caused by a complex interaction of genetics and environmental factors. ${ }^{1}$ Type 2 DM is an extremely heterogenous disease and no single cause is adequate to explain the progression from normal glucose tolerance to diabetes. The fundamental molecular defects in type $2 \mathrm{DM}$ are insulin resistance and impaired insulin secretion results from a combination of environmental and genetic factors. ${ }^{2}$ It is a major public health concern both in developing and developed countries. It is one of the four priority non-communicable diseasesalong with cardio-vascular disease, malignancy and chronic respiratory diseases. Complications of DM are the cause of many deaths. It is the leading cause of adult blindness, amputation, renal failure, heart attacks and strokes. ${ }^{3}$

A minor hemoglobin derivative called glycated

${ }^{1}$ Dr. Farhana Khondker, Assistant Professor, Department of Biochemistry, Anwer Khan Modern Medical College, Dhaka

${ }^{2}$ Prof. Dr. Manindra Nath Roy, Professor \& Head, Department of Biochemistry, Sir Salimullah Medical College, Dhaka

${ }^{3}$ Dr. Purnima Rani Saha, Assistant Professor, Department of Biochemistry, Sir Salimullah Medical College, Dhaka

${ }^{4}$ Dr. Rubena Huq, Assistant Professor, Department of Biochemistry, Sir Salimullah Medical College, Dhaka

${ }^{5}$ Dr. Rumana Ahmed, Assistant Professor, Department of Biochemistry, Care Medical College, Dhaka

${ }^{6}$ Dr. Sumona Biswas, Lecturer, Department of Biochemistry, Shaheed Suhrawardy Medical College, Dhaka

*Corresponding author

Date of submission: 27.8.2017, Date of acceptance: 17.11.2017

AKMMC J 2018; 9(1) : 29-33 
hemoglobin $\left(\mathrm{HbA}_{1 \mathrm{c}}\right)$ is produced by glycation, the covalent binding of glucose to hemoglobin. In assessment of glycemic status, the percentage of $\mathrm{HbA}_{1 \mathrm{c}}$ represents the integrated values of glucose over preceding 6 to 8 weeks. ${ }^{2}$ At the present time, the HbA1cis used worldwide as the marker of long term glycemic control and also a therapeutic target in the prevention and delay of the development of hyperglycemic complications. ${ }^{4,5}$

It is recently recognized that increased body iron stores are associated with the development of glucose intolerance, type $2 \mathrm{DM}$ and insulin resistance syndrome. $6,7,8$ Some researches had shown that, there is difficult control of hyperglycemia in patients with iron overload ${ }^{7,9}$ Normally, there is little ferritin in human plasma proportionate to the total stores of iron in the body. Plasma ferritin levels are thus considered to be an indicator of body iron stores. Ferritin is one of the key proteins that play an important role in regulating iron homeostasis. ${ }^{10}$

The mechanism for the association between serum ferritin and type $2 \mathrm{DM}$ is not established yet, but iron deposition in the liver may cause insulin resistance by interfering the ability of insulin to suppress hepatic glucose production. ${ }^{8,9}$ Iron is auto oxidized to form iron-oxygen complexes. These free radicals can change membrane properties and result in tissue damage. ${ }^{11,12}$ Oxidative stress can also lead to hyperglycemia through disturbed glucose metabolism. ${ }^{13}$ This study was performed in order to find a link between serum ferritin and DM and also $\mathrm{HbA}_{1 \mathrm{c}}$ as a blood glucose control marker in diabeticpatients.

\section{Materials and Method}

This case-control study was conducted in Dhaka from July 2013 to December 2014 and was carried out in a group of diabetic patients who had been referred to the outpatient department of Ibrahim General Hospital \& DCEC, and a normal control group. Patients with Chronic kidney disease, Chronic liver disease, individuals on corticosteroid therapy and other states associated with altered serum ferritin like haemochromatosis, bleeding disorder, chronic alcoholics, anaemia were excluded from our study. Also the individuals with repeated blood transfusion were not included. Our criteria for the diagnosis of anemia were based on laboratory investigation and a hemoglobin level of lessthan 13 $\mathrm{g} / \mathrm{dl}$. in male and $12 \mathrm{gm} / \mathrm{dl}$ in females. In case of CRP level as the acute phase protein marker the cutoff value was taken as $6 \mathrm{mg} / \mathrm{dl}$.

The control group consisted of individuals who had no history of diabetes mellitus. They had fasting blood sugar levels of less than $6 \mathrm{mmol} / \mathrm{L}$ and hemoglobin levels of more than the cut-off value. They did not have a history of medication use, and were matched with the diabetic group regarding age, sex and BMI. One standard questionnaire was completed for each subject, which included their personal data, drug usage, disease history and physical examination. Weight and height were measured by a standard device and body mass index (BMI) was calculated based on weight / (height)2 formula. The blood sugar was measured after $12 \mathrm{~h}$ of fasting by glucose oxidase method in the biochemical laboratory of Sir Salimullah Medical College, Dhaka. HbA1cby modified HPLC method and ferritin by by DRG Ferritin ELISA kit in the BSMMU laboratory. Results were analyzed with SPSS software and t-test was used for quantitative variables, Chi-square test for qualitative variables and Pearson's regression for correlation between variables. Odds Ratio was also done to find the risk factor.

\section{Results}

The mean age of the diabetic patients was 54.91 $( \pm 6.46)$ years and that of the controls was 53.19 $( \pm 7.31)$ years. $56.5 \%$ of the cases were male and $43.5 \%$ were female. On the other hand, in the control group $58.7 \%$ was male and $43.1 \%$ was female. Mean BMI was $27.95( \pm 2.21) \mathrm{kg} / \mathrm{m}^{2}$ and $27.19( \pm 2.98) \mathrm{kg} / \mathrm{m}^{2}$ in cases and controls respectively.There was no significant differences between the two groups regarding age, sex and BMI. Table I reflects these demographic features of the study subjects.

Table II Shows the comparison between the case \& control group regarding $\mathrm{Hb}$ concentration, fasting plasma glucose (FPG), $\mathrm{HbA}_{1 \mathrm{c}}$ and serum ferritin. 
Table III showing the association between serum ferritin among the subjects with normal level $(\leqslant 6 \%)$ of HbA1c and the subjects with high level $(\geqslant 6.1 \%)$ of HbA1c. $150 \mu \mathrm{gm} / \mathrm{L}$ was the cut off value of Serum ferritin level. Most of the study subjects with normal of $\mathrm{HbA}_{1 \mathrm{c}}(\%)$ were showing the lower Ferritin level and vice versa.

There was positive and significant correlation between $\mathrm{HbA}_{1 \mathrm{c}}$ and serum ferritinin diabetic subjects as shown in Fig I.

On the other hand, the control group was also positively correlated regarding serum ferritin and $\mathrm{HbA} 1 \mathrm{c}$, but their correlation was not statistically significant. (Fig II)

Table IV is for the measurement of serum ferritin as a risk factor for type 2 diabetes mellitus. In this study, OR of 11.64 was observed which indicates that the individuals with higher serum ferritin level are in 11.64 times at risk to develop type $2 \mathrm{DM}$ than those with lower serum ferritin level.

Table-I: Demographic characteristics of the subjects in groups

\begin{tabular}{cccc}
\hline $\begin{array}{c}\text { Demographic v } \\
\text { ariables }\end{array}$ & \multicolumn{2}{c}{ Group } & \\
\cline { 2 - 3 } & $\begin{array}{c}\text { Case } \\
\text { (Type 2 diabetic) } \\
\mathbf{n = 4 6}\end{array}$ & $\begin{array}{c}\text { Control } \\
\text { Non diabetic) } \\
\mathbf{n = 4 6}\end{array}$ & p value \\
\hline Age (mean \pm SD) & $54.91 \pm 6.46$ & $53.19 \pm 7.31$ & 0.236 \\
Male n (\%) & $26(56.5 \%)$ & $27(58.7 \%)$ & \\
Femalen(\%) & $20(43.5 \%)$ & $19(41.3 \%)$ & 0.833 \\
& & & \\
BMI (kg/m $)$ & $27.95 \pm 2.21$ & $27.19 \pm 2.98$ & 0.150 \\
\hline
\end{tabular}

Student's 't' test was done

Table-II: Comparison between the study groups regardingBiochemical parameters

\begin{tabular}{cccc}
\hline $\begin{array}{c}\text { Biochemical } \\
\text { parameters }\end{array}$ & $\begin{array}{c}\text { Case } \\
\text { Mean }(\mathbf{n}=46)\end{array}$ & $\begin{array}{c}\text { Control } \\
\text { Mean }(\mathbf{n}=46)\end{array}$ & $\begin{array}{c}\mathbf{P} \\
\text { value }\end{array}$ \\
\hline FPG (mmol/L) & $7.88 \pm 1.57$ & $5.09 \pm 0.65$ & 0.001 \\
HbA1c (\%) & $8.53 \pm 2.31$ & $5.44 \pm 0.48$ & 0.001 \\
S. Ferritin & $197.97 \pm 75.99$ & $64.24 \pm 27.83$ & 0.001 \\
$(\mu \mathrm{gm} / \mathrm{L})$ & $13.07 \pm 1.27$ & $13.42 \pm 0.98$ & 0.726 \\
$\mathrm{Hb}(\mathrm{gm} \%)$ & & \\
\hline
\end{tabular}

Student's 't' test was done
Table-III: Association of serum ferritin level with $\mathrm{HbA}_{1 \mathrm{c}}$ among the study subjects.

\begin{tabular}{cccc}
\hline HbA1c (\%) & $\begin{array}{c}\text { Serum ferritin Serum ferritin } \\
(\leq \mathbf{1 5 0} \boldsymbol{\mu} \mathbf{g m} / \mathbf{L})\end{array}$ & $\mathbf{p}$ value \\
\hline$\leq 6$ & 48 & $\mathbf{1 5 0} \boldsymbol{\mu} \mathbf{g m} / \mathbf{L})$ & \\
$\geq 6.1$ & 11 & 29 & $\leq 0.001$ \\
\hline
\end{tabular}

Chi-squire test was done

Table-IV: Risk measurement of serum ferritin in type 2 DM.

\begin{tabular}{cccc}
\hline $\begin{array}{c}\text { Serum Ferritin } \\
(\mu \mathbf{g m} / \mathbf{L})\end{array}$ & $\begin{array}{c}\text { With DM } \\
(\mathbf{n}=\mathbf{4 6})\end{array}$ & $\begin{array}{c}\text { Without DM } \\
(\mathbf{n}=\mathbf{4 6})\end{array}$ & OR \\
\hline$\geq 151$ & 34 & 9 & \\
$\leq 150$ & 12 & 37 & 11.64 \\
\hline
\end{tabular}

Serum Ferritin

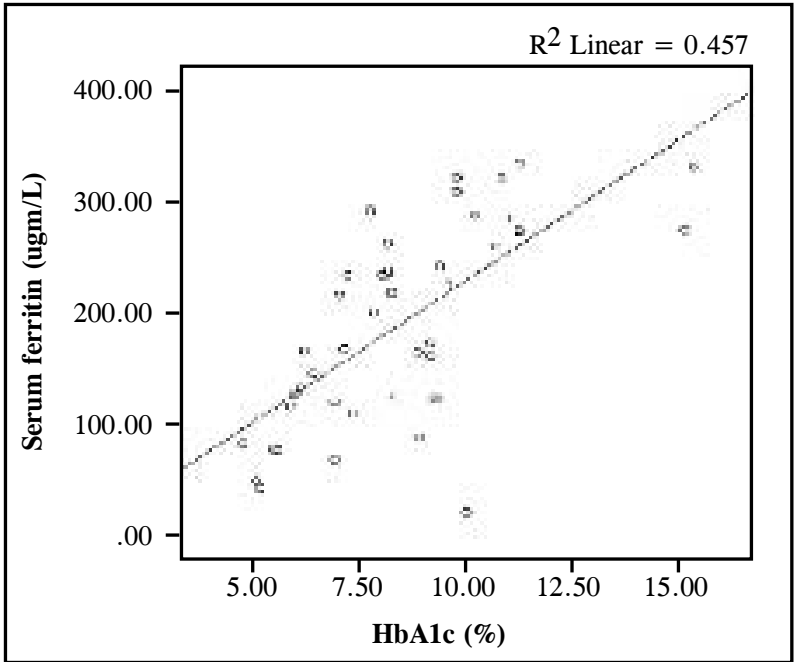

Figure-I: Correlation between serum ferritin and $\mathrm{HbA1c}$ in cases

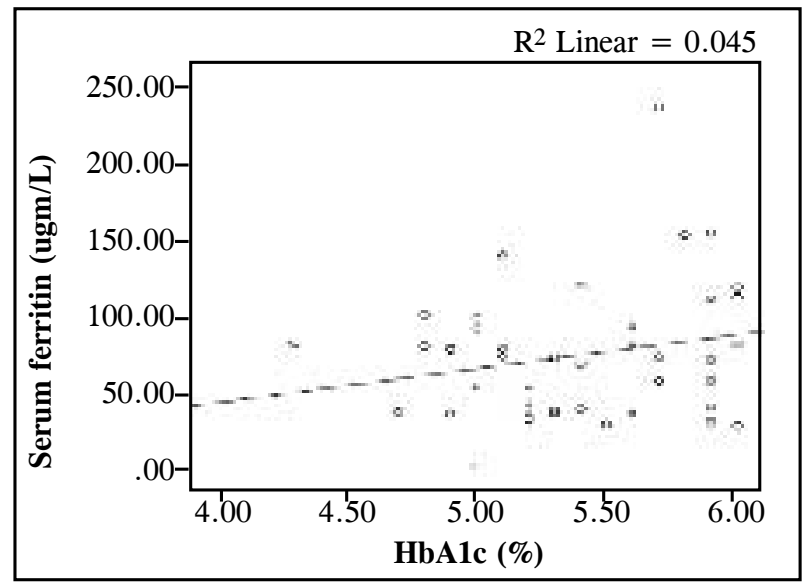

Figure-II: Correlation between serum ferritin and HbA1c between controls. 


\section{Discussion}

Type 2 diabetes mellitus is a global problem that causes many life-threatening complications. Impaired insulin secretion as well as insulin resistance are the main factors in the development of type 2 DM. Now-a-days, increased serum iron store, indicated by serum ferritin is thought to have an influence in the development of type $2 \mathrm{DM}^{8}{ }^{8}$

In this study, cases were the diabetic patients. So, their fasting plasma glucose level were higher in comparison to the controls. There was significant difference of HbA1c between cases and controls $(p \leqslant 0.001)$. Similar observation was found in other two studies in India and China. ${ }^{14,15}$

The mean serum ferritin level of the diabetic patients was significantly higher $(<0.001)$ than that of the controls. These findings are consistent with the studies conducted by Raghavani.16We have also found significant $(\mathrm{p} \leqslant 0.001)$ association between HbA1c and serum ferritin. Among the subjects (both cases and controls), those with higher ferritin level also showed high HbA1c. So higher serum ferritin level was associated with high HbAlc. This finding corresponds with a study in India done by Prashant et al. ${ }^{17}$ Another study found in general population that increased body iron store was possibly associated with the occurance of glucose intolerance, type $2 \mathrm{DM}$ and gestational diabetes. ${ }^{11}$

We also found that serum ferritin level was positively \& significantly correlated withHbAlc $(\mathrm{p}=0.001)$ in diabetic patients. Similar findings were evident in a study done by Raj et al. (2013) in India. Raghavani et al shown in their study that there was strong correlation of ferritin with FPG and moderate correlation with HbA1c. ${ }^{16} \mathrm{~A}$ significant correlation between iron and $\mathrm{HbA1c}$ was found in a study in India. ${ }^{18}$

From the above discussion, it seems that ferritin may have a role in the pathogenesis of type $2 \mathrm{DM}$. The mechanism for the association between serum ferritin and type $2 \mathrm{DM}$ is not yet established. But iron deposition in the liver may resist the action of insulin on liver (Mozulski et al., 2001\& Fernandez Real et al., 2002). ${ }^{11,19}$ There is some evidence that iron overload also affects skeletal muscle. Deposited iron in muscle decreases glucose uptake because of muscle damage. Increased accumulation of ironin the pancreas causes decreased insulin synthesis and secretion (Fernandez Real et al., 2002). ${ }^{11}$

Besides insulin resistance, iron may also has a role in DM through oxidative stress. Pancreatic $\beta$-cells, which are at increased risk of oxidative damage may be the cause of developing diabetes (Lenzen et al., 1996). However, in a study in Iran by Sharifiet al. found no correlation of serum ferritin with $\mathrm{HbAlc} .{ }^{20}$ Another study in Indiaalso did'nt find significant correlation between serum ferritin and HbA1c. ${ }^{14}$

There was positive correlation of serum ferritin with $\mathrm{HbA}_{1 \mathrm{c}}(\mathrm{p}=0.06)$ in the non-diabetic controls also, but that was not significant. Similar finding was observed in another study done by Sumesh Raj et al in India. ${ }^{21}$

It was also evident in our study that serum ferritin is a strong risk factor $(\mathrm{OR}=11.64)$ for type $2 \mathrm{DM}$. Scholl (2005) had performed a study on women and found that high ferritin levels $(170 \mathrm{ng} / \mathrm{ml})$ in women augment the risk of developing type 2 DM. ${ }^{23}$ This augmentation was about three times within ten years. A large population based study in Taiwan by Chang et al. (2013) had shown that individuals with moderately high serum ferritin level had 1.3 times (95\% CI) higher risk for developing hyperglycemia. They also shown that this risk increased to 2.16 times $(95 \%$ CI) for individuals with severely high serum ferritin level. ${ }^{22}$

Therefore, this study shows that Serum ferritin is positively correlated with $\mathrm{HbA} 1 \mathrm{c}$ in diabetic subjects and also a potential risk factor for type 2 diabetes mellitus. Our findings can be explained well enough by the findings of other studies.

\section{Conclusion}

Our findings of the present study supported that there is significant increase in serum ferritin in diabetes mellitus compared to control group. Positive correlation between $\mathrm{HbAlc}$ and serum ferritin hasalso beenfound. And hyper ferritinemia may be one of the causes for decreased insulin production and development of insulin resistance in diabetes mellitus. 


\section{Conflict of interest: None}

\section{References}

1. Alvin CP. Diabetes Mellitus, Harrison's Principles of Internal Medicine $17^{\text {th }}$ ed: New York. NY: Mc Grew Hill. 2008: p. 2275-304.

2. Burtis CA, Ashwood ER, Bruns DE. Teitz textbook of clinical chemistry and molecular diagnostics $4^{\text {th }}$ ed: New Delhi, Saunders Harcourt. 2006: p. 856-859 \& p.869-85

3. Champe PC, Harvey RA and Ferrier DR.Lippincott's Illustrated ReviewsBiochemistry $4^{\text {th }}$ ed: Philadelphia, USA. Lippincott Williams \& Wilkins. 2008: p. 337341 \&p. 33-35.

4. Edelman D, Olsen MK, Dudley TK, et al. Oddone EZ: Utility of hemoglobin $\mathrm{A}_{1 \mathrm{c}}$ in predicting diabetes risk. J Gen Intern Med 2004; 19: 1175-1180.

5. Sato KK, Hayashi $\mathrm{T}$, Harita N, Yoneda $\mathrm{T}$, Nakamura Y, Endo G, Kambe H. Combined measurement of fasting plasma glucose and $\mathrm{A}_{1 \mathrm{c}}$ is effective for the prediction of type 2 diabetes: the Kansai Healthcare Study. Diabetes Care 2009; 32: 644-646.

6. Fernandez-Real JM and Lopez-Bermejo A. Cross talk between iron metabolism and diabetes. Diabetes 2002; 51: 2348-54

7. Dmochowshi K, Finegood DT, Framecombe W, Tyler B, Zinman B. Factors determining glucose tolerance in patients with thalassemia major JClinEndocrinolMetab 1993; 77: 478-83.

8. Wrede CE, BuetherR, Bollheimer LC, Scholmerich J, Palitzsch KD, Hellebrand C. Association between serum ferritin and insulin resistance syndrome in a representative population. Eur J Endocrinol 2006; 154: 333- 40.

9. Suvarna J, Ingle $\mathrm{H}$, Deshmukh CT. Insulin resistance and beta cell function in chronically transfused patients of thalassemia major. IndPediatr 2006; 43: 393-400.

10. Murry RK, Bender DA, Botham KM, et al. Harper's illustrated biochemistry $29^{\text {th }}$ ed: New York. Mc Graw Hill. 2012: p.635

11. Fernandez Real JM, Penarroja G, Castro A. Blood letting in high-ferritin type 2 diabetes: effects on insulin sensitivity and $\beta$-cell function. Diabetes 2002; 51: 1000-1004.
12. Greer JP. Wintrobe's clinical hematology $12^{\text {th }}$ ed: Philadelphia, USA. Lippincott William \& Wilkins. 2009: p. 857-861.

13. Chasteen ND. Ferritin: uptake, storage and release of iron. Met Ions BiolSyst 1998; 35: 479-514.

14. Jagannatha, SB and Nagarajappa K. Study of serum high-sensitivity C-reactive protein, Ferritin, Insulin, C-peptide and glycated hemoglobin in patients with type 2 Diabetes Mellitus. M. D. thesis. Rajiv Gandhi University of Health Science, Bangalore, India. 2014; pp. 60-62.

15. Chang JS, Lin SM, Jane CJ, et al. Serum ferritin and risk of Metabolic Syndrom, a population-based study. Asia pac J Clin Nutr 2013; 22: 400-407

16. Raghavani PH and Sirajwala H. Serum ferritin level in patients with type 2 diabetes mellitus. IJBAR 2014; 5: 272-274.

17. Prashant V. and Meera KS. A study of Serum Ferritin and Serum Myeloperoxidase levels in type 2 diabetic males on oral hypoglycemic agents. M.D. thesis. Rajiv Gandhi university of Health Science, Bangalor, India. 2014; pp. 83-85

18. Shetty JK, Prakash M Ibrahim MS. Relationship between free iron andglycated haemoglobin inuncontrolled type 2 diabetes patients associated with complications. Indian Journal of Clinical Biochemistry 2008; 23: 67-70

19. Mozulski DK, Grajesjcyjak W, Gawlik B. Role of hemochromatosis C282 Y and H63D mutations in HFE gene in development of type 2 Diabetes. Diabetes care 2001; 24: 1187-1191.

20. Sharifi F, NasabN, Zadeh H. Elevated serum ferritin concentrations in prediabeteic subjects. Diabetes Vascular Disease Research 2008; 5: $15-18$

21. Sumesh R and Rajan GV. Correlation between elevated serum ferritin and $\mathrm{HbA}_{1 \mathrm{c}}$ in type 2 diabetes mellitus. Int J Res Med Sci 2013; 1: 125.

22. Chang JS, Lin SM, Jane CJ, et al. Serum ferritin and risk of Metabolic Syndrom, a population-based study. Asia pac J Clin Nutr 2013; 22: 400-407

23. Scholl TO. Iron status during pregnancy: setting the stage for mother and infant. American Journal of Clinical Nutrition.2005; 81: 1218-22. 